The Impact of Total Quality Management and Corporate Social Responsibility on the Financial Performance of Higher Education Institutions: A Review with a Focus on Institutions in the United Arab Emirates

Laith Naji Abed Almuntfjy and Tan Owee Kowang

To Link this Article: http://dx.doi.org/10.6007/IJARBSS/v11-i3/8520

DOI:10.6007/IJARBSS/v11-i3/8520

Received: 09 January 2021, Revised: 04 February 2021, Accepted: 17 February 2021

Published Online: 06 March 2021

In-Text Citation: (Almuntfjy \& Kowang, 2021)

To Cite this Article: Almuntfjy, N. A. L., \& Kowang, T. O. (2021). The impact of Total Quality Management and Corporate Social Responsibility on the Financial Performance of Higher Education Institutions: A Review with a Focus on Institutions in the United Arab Emirates. International Journal of Academic Research in Business and Social Sciences, 11(3), 111-121.

Copyright: (c) 2021 The Author(s)

Published by Human Resource Management Academic Research Society (www.hrmars.com)

This article is published under the Creative Commons Attribution (CC BY 4.0) license. Anyone may reproduce, distribute, translate and create derivative works of this article (for both commercial and non-commercial purposes), subject to full attribution to the original publication and authors. The full terms of this license may be seen at: http://creativecommons.org/licences/by/4.0/legalcode

Vol. 11, No. 3, 2021, Pg. 111 - 121 


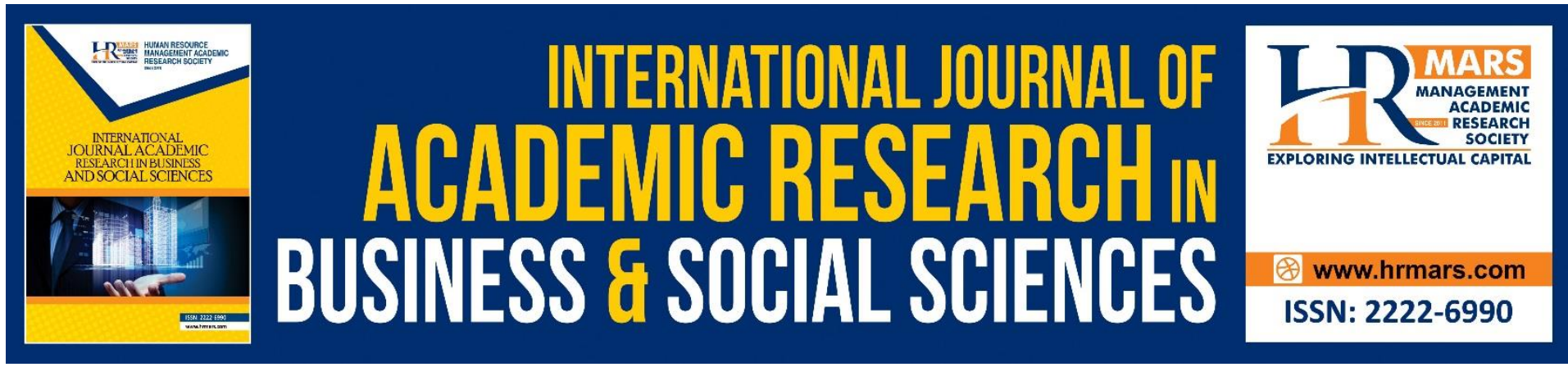

\title{
The Impact of Total Quality Management and Corporate Social Responsibility on the Financial Performance of Higher Education Institutions: A Review with a Focus on Institutions in the United Arab Emirates
}

\author{
Laith Naji Abed Almuntfjy and Tan Owee Kowang \\ Department of Business Admin Azman Hashim International Business School (T08) Universiti \\ Teknologi Malaysia, 81310 UTM Skudai, Johor, Malaysia. \\ Email: oktan@utm.my
}

\begin{abstract}
Many of the studies and researchers published in Total Quality Management (TQM) and Corporate Social Responsibility (CSR) have confirmed an interest in total quality in the education sector. Increasingly, this concern with the growing awareness of this approach's significance and the critical role of the TQM in providing quality education services when applied effectively. In United Arab Emirate (UAE), many private higher education institutes (PHEl's) face many challenges related to their traditional management systems. There is a rapid growth in the private higher education sector in UAE in terms of the number of institutions, students, and employees. After decades of development, education quality in private higher education institutes (PHEIs) has become one of the main considerations. The Ministry of Higher Education (MOHE) continuously monitored the improvement measures applied in such institutions. However, some challenges emerged in many 'PHEl's across the $\mathrm{UAE}$, most of which are associated with the growing demands to offer quality education services. In response to the high demand for quality education, some of the existing 'PHEl's in UAE have been reportedly poor in their ratings. The MOHE even terminated some other institutes as they fall below expectations. This undertaken research aims to assess and propose solutions to the below problems. This study reviews the implications of adopting TQM and CSR management approaches on higher education institutes' performance, focusing on PHEI's in UAE.
\end{abstract}

Keywords: Total Quality Management (TQM) and Corporate Social Responsibility (CSR), Private Higher Education Institutes (PHEl's), United Arab Emirates (UAE) 


\section{Introduction}

Establishing a knowledge-based economy in any country requires treating education as one of the top priorities. In fact, the educational choices available to the public determines the progress and prosperity of a country. Apart from training people to deal with challenges and complexities, education in general is a lever for enhancement to deal with challenges and complexities. Education in general is a lever for enhancing economic growth. Higher education, in particular, enables acquiring greater economic rewards and social mobility in many countries around the world (Abu-Saad, 2016; Zhu \& Zhang, 2017).

In the past decades, United Arab Emirates (UAE) has accomplished a significant level of growth and development (about 13 percent growth in GDP since 2000). The sustainability of such development in the UAE is linked to the transition from a traditional economy to a knowledge-driven economy (Ahmed \& Abdalla Alfaki, 2013; Ashour \& Fatima, 2016). The fact that higher education is an enabler for economy has been considered in the government plans. For example, in the 2015 horizon plan adopted by the Dubai Government, improving the quality and accessibility to education represents a core strategic thrust in sustaining and enhancing economic prosperity and achieving social development goals (Thorpe \& Connell, 2013).

Higher education institutions' history is dated back to 1977 when UAE University was established as the first institution. From that moment on, the higher education sector expanded dramatically due to public and private investments. In the past few years, there has been a remarkable increase in enrollment in higher education across UAE. Fig. 1 depicts the drastic rise in enrollment in higher education institutes from 2008 through 2013.

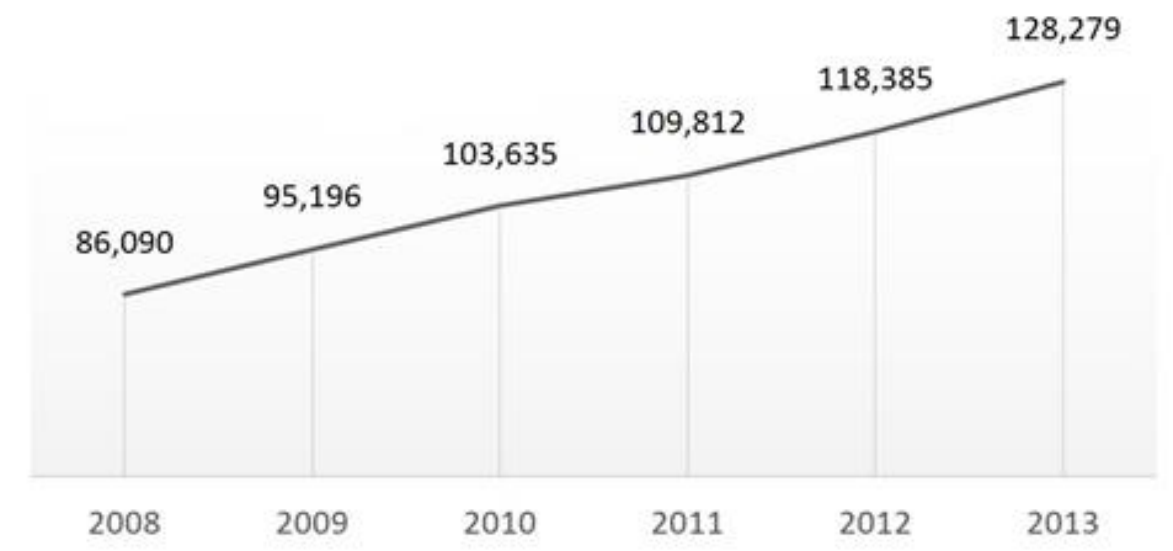

Fig. 1. Higher education enrollment in UAE from 2008 through 2013. Modified After National Qualifications Authority

Private higher education institutes (PHEI's) contribute significantly to the overall higher education in UAE. Fig. 2 shows the proportions of enrollment in PHEI's PHEl's and public higher education institutes in Dubai, Abu Dhabi, and the rest of UAE. 


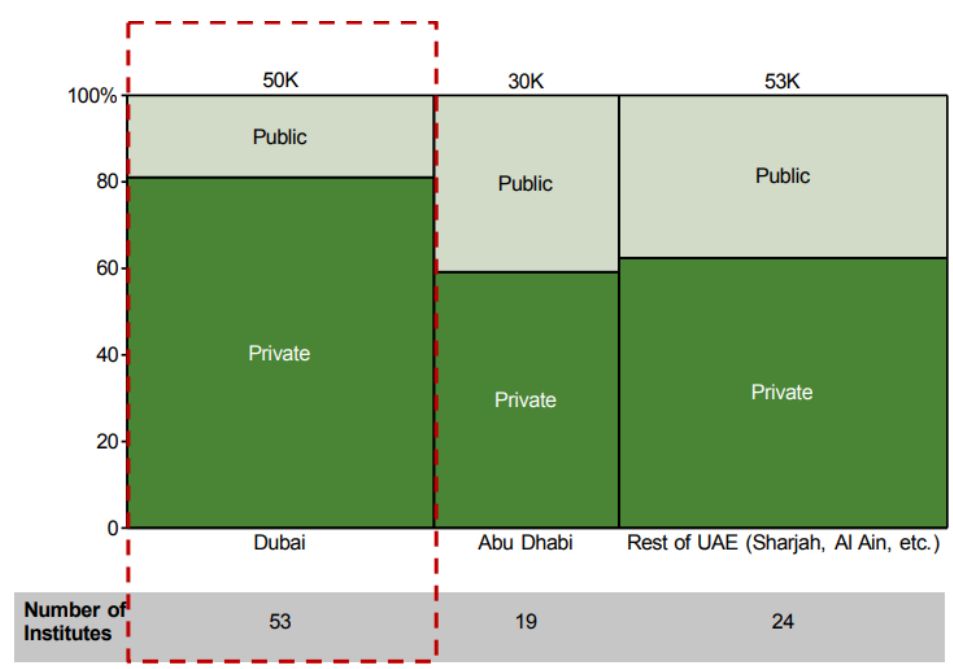

Fig. 2. Private and public higher education enrolment in UAE by, 2014

The private universities in UAE are either owned and controlled locally by some Emirati local organization, or from abroad by some foreign institution of higher education. At least $65 \%$ of the existing 'PHEl's in UAE were found after 2005 (Mahani \& Molki, 2011; Marshall, 2019). Certainly, some of the 'PHEl's were presumably motivated by the likelihood of being able to generate easy revenue in a wealthy country. Other 'PHEl's seemingly have not done enough market research prior to their decision to operate in UAE. The drastic increase in PHEI'PHEI's in UAE is associated with issues and problems. Some private higher education institutions had failed to achieve their staffing targets. For example, in May 2009, George Mason University, a branch for an American institution, had to close its campus in Ras Al Khaimah, less than three years after it opened (Wilkins, 2010; Wilkins, Balakrishnan, \& Huisman, 2012). In December 2009, the New York Times reported that international branch campuses in Dubai were struggling following the collapse of the 'emirate's overheated economy (Wilkins et al., 2012). Other 'PHEl's were reported to face several problems related to their ability to attract their target to number of students. For example, Michigan State University, which started classes in August 2008, had only 85 undergraduates at the end of 2009, and Rochester Institute of Technology, which also started operations in August 2008, had only 50 students. Murdoch University, based in Perth, Western Australia, which started operations in Dubai in the summer of 2008, admitted that the number of students it had in its second year was almost 30 percent below its target. Apparently, it will take some 'PHEl's substantially longer to achieve break-even than they had budgeted, and some may even not accomplish that point. Since too often quantity is achieved at the expense of quality, it is argued that educational authorities such as the Ministry of Higher Education (MOHE) should give urgent attention to quality during times of rapid expansion. Several of the earliest associates at Dubai Polytechnic suffered at least 50\% dropout and failure rates (Wilkins et al., 2012). Students who were used to educate, teacher-centered secondary education found it difficult to adjust to the student - centered and independent learning. A high proportion of students were also found to have unsatisfactory written English skills.

Modern organizations must accomplish total quality in a dynamic and extremely competitive world of service delivery. Higher education institutions (HEI's) in UAE face multiple and diverse challenges that restrict their performance and could even turn into threats for their sustainability (Wilkins et al., 2012). Implementing Total Quality Management (TQM) 
Corporate Social Responsibility (CSR) approaches were described by many authors to positively impact organizations' transformation process. Such ability is possibly attributed to their elements such as continual improvement and customer focus (Bon \& Mustafa, 2013; Hoang, Igel, \& Laosirihongthong, 2011; Karani \& Bichanga, 2012). In the context of higher education TQM and CSR have become an entry point for a change of organizations and a target for most institutions (Kayani, 2012). TQM is defined as a way of management, which leads the success of organization by meeting 'customers' expectation (Evans \& Lindsay, 2013). It is also described TQM as a management system that takes into consideration continuous feedback to improve the quality of services products by adopting comprehensive practices and approaches.

Many of the studies and researchers published in TQM and CSR have confirmed that there is an interest in the issue of total quality in the education sector. Increasingly, this concern with the growing awareness of the importance of this approach and the important role of the TQM in providing quality education services when applied effectively (Jain, Sinha, \& Sahney, 2011; Psomas \& Antony, 2017). As mentioned earlier, many 'PHEI's in UAE faces lots of challenges, most of which are related to their traditional management systems. This study aims to discuss the implications of adopting TQM and CSR management approaches on the performance of 'PHEI's in UAE.

\section{Literature Review on Higher education in UAE}

Since the United Arab Emirates' establishment as a federal state in 1971, its higher education system has experienced substantial changes (Ashour, 2019). In 1971, 74 schools were operating throughout the country (Mahani \& Molki, 2011). Traveling overseas was the only option for seeking higher education. The first state university, United Arab Emirates University (UAEU), was established in 1977 (Ashour \& Fatima, 2016). In 1988, Higher Colleges of Technology was then founded as a vocational school before it started offering graduate and postgraduate degrees. The third public university, Zayed University, was founded by the federal government in 1998 (Mahani \& Molki, 2011). Ever since, the enrollment in higher education has increased, reflecting Emiratis's desire to cope with the modern world. The UAE constitutions acknowledge the role of education in the development of the country. Public universities offer free education for UAE nationals. Determinedly, the UAE government had decided in 1990s to position the country as a regional higher education hub. In 2017, higher education institutions were reported to exceed 100 institutions, most of which have modern, attractive, well-designed, and well-resourced campuses (Nasir, 2017).

There are four recognized higher 'education's sub - hubs across UAE, i.e., Abu Dhabi, Dubai, Ras al Khaimah and Sharjah, each has its unique growth strategy (Wilkins, 2019). In Abu Dhabi, the aim is to achieve quality over quantity in higher education. Initially, the approach adopted by the Abu Dhabi government involved inviting reputable overseas institutions to open branch campuses. The focus was then changed to develop the existing local universities. In 2017, Khalifa University merged with Masdar Institute of Science and Technology and The Petroleum Institute. According to the 2018 Times Higher Education World University Rankings, the new enlarged Khalifa University, with over 5,000 students, has become recognized as the second-ranked university in the Arab World (behind King Abdulaziz University in Saudi Arabia), and among the top 350 universities in the world. 
In Sharjah, providing much of the new higher education capacity is a state responsibility. In 1997, the ruler of Sharjah established two large general universities: the American University of Sharjah and the University of Sharjah. 'Sharjah's strategy has been to target quality over quantity, and within 20 years of their establishment, both institutions are ranked among the 'world's top 1,000 universities in the 2018 Times Higher Education World University Rankings 2018.

'Dubai's strategy for increasing higher education capacity has been somewhat different to Abu Dhabi and Sharjah. It has adopted a free-market approach, welcoming any institution that meets its quality standards. Higher education institutions have been established by individuals, companies, semi-government bodies, and foreign universities. For example, Al Ghurair University was established by the Al Ghurair Group, a conglomerate with diverse business interests in manufacturing and real estate, while the University of Dubai is a whollyowned subsidiary of the Dubai Chamber of Commerce and Industry. The Emirate of Dubai has established a number of free zones that are attractive to both domestic and foreign institutions. The two best-known free zones are Dubai International Academic City (DIAC) and Dubai Knowledge Park (DKP). The Knowledge and Human Development Authority (KHDA) is responsible for higher education regulation and accreditation in 'Dubai's free zones. In 2017, 38 higher education institutions were operating in these free zones, 24 of which were the IBCs or international study centers of foreign universities (Wilkins, 2019). For example, Amity University (India), BITS Pilani (India), Curtin University (Australia), Heriot-Watt University (UK), Manipal University (India), Murdoch University (Australia), and the University of Birmingham (UK) are based at DIAC. At the same time, Islamic Azad University (Iran), Middlesex University (UK) and the University of Wollongong (Australia) are located at DKP. With a total of 62 higher education institutions (Wilkins, 2019), the Emirate of Dubai has a vibrant but very competitive higher education market. It is vital for institutions to each provide unique offerings to distinct market segments.

Ras al Khaimah, the most northerly of the emirates, is widely regarded as the "'low cost, low quality"' option. Until 2017, any organization could open a university in Ras Al 'Khaimah's free zone without any guarantee of quality, accreditation or even provision of qualifications (Wilkins, 2019). However, since 2017, Ras al Khaimah has introduced new requirements, which are modelled on the system of quality assurance in the UK. All IBCs must now be fully accredited in their home country before they can be registered for Ras al Khaimah's operation.

\section{Private Higher Education in UAE}

In $\mathrm{UAE}$, there are two distinct categories for private higher education institutes (PHEIs) universities: either owned and controlled locally, by individual emirates or local organizations or from abroad, by foreign institutions of higher education that have established branch campuses. The American University of Sharjah, the University of Dubai, established as Dubai Polytechnic by the Dubai Chamber of Commerce and Industry; Paris-Sorbonne University Abu Dhabi, established by the Abu Dhabi Education Council; and Al Ghurair University, owned by the Al Ghurair Group, a company with diverse interests, which include a bank, a shopping mall and a cement business are examples of private locally owned universities. The first international branch campus was established in Dubai in 1993 by the University of Wollongong, an Australian - based university. Many others have since opened, including 
Middlesex University and Heriot-Watt University from UK universities branches (Wilkins, 2010).

Most of the new PHEls are in Dubai and Abu Dhabi, the two emirates with the largest populations. Ras al Khaimah is another emirate that successfully attracted some foreign institutions. Although the private education system is open to the entire UAE population, both UAE nationals and expatriates are expected to pay full tuition fees. A limited number of scholarships are commonly available for study at private institutions, offered either by the government or the institutions themselves. Roughly $30 \%$ of UAE national undergraduates are currently studying at a private institution (Wilkins, 2019). Commonly, those UAE nationals who choose private higher education are motivated by the fact that they would have a chance to study subjects not offered at the federal institutions. Besides, private higher education institutes allow gaining a more highly respected degree from overseas, enhancing career prospects in the international labor market (Wilkins, 2010).

Despite the fact that the UAE plans to move to a knowledge-based economy, there are still challenges seen with the quality of graduates produced in the nation. It is found that there is immature growth of graduate studies. Besides, the quality of graduates coming out of universities not meeting the requirements of the market (Ashour \& Fatima, 2016).

The establishment of about 65\% of the existing PHEls in the UAE is dated back to after 2005. Many of these institutes came to the UAE in quite fast speed, which is often referred to as 'education gold 'rush' (Ashour \& Fatima, 2016). The prospect of easily generating revenue in a wealthy country was one of the motivations for many of the PHEls which opened in the UAE (Vikash, 2015). Such speedy situations apparently did not allow enough time for many of the PHEls to do proper market research before setting up (Wilkins, 2010).

Some private higher education institutions had failed to achieve their staffing targets. For example, in May 2009, George Mason University, a branch for an American institution, had to close its campus in Ras Al Khaimah, less than three years after it opened (Wilkins, 2010; Wilkins et al., 2012). In December 2009, the New York Times reported that international branch campuses in Dubai were struggling following the collapse of the 'emirate's overheated economy (Wilkins et al., 2012). Other 'PHEl's were reported to face several problems related to their ability to attract their target to number of students. For example, Michigan State University, which started classes in August 2008, had only 85 undergraduates at the end of 2009, and Rochester Institute of Technology, which also started operations in August 2008, had only 50 students. Murdoch University, based in Perth, Western Australia, which started operations in Dubai in the summer of 2008 , admitted that the number of students it had in its second year was almost 30 percent below its target.

Apparently, it will take some 'PHEl's substantially longer to achieve break-even than they had budgeted, and some may even not accomplish that point. Since too often quantity is achieved at the expense of quality, it is argued that educational authorities such as Ministry of Higher Education (MOHE) should give urgent attention to quality during times of rapid expansion. Several of the earliest associates at Dubai Polytechnic suffered at least $50 \%$ dropout and failure rates (Wilkins et al., 2012). Students who were used to educate, teacher-cantered secondary education found it challenging to adjust to the student-cantered and independent 
learning. A high proportion of students were also found to have unsatisfactory written English skills.

\section{TQM and CSR in Higher Education}

The environment which higher education institutions (HEIs) operate is increasingly complex and challenging. Competition has increased, and previously anticipated government funding has become scarce (Dumond \& Johnson, 2013). This is evident in many countries and especially that experience economic-financial crisis. In such circumstances, HEls must succeed in a financial sense, or go out of business. So, driven by the struggle to survive, these organizations seek to meet and exceed their 'customers' expectations while also focusing on cost reduction and increased efficiency. HEls also cope with the current competitive world by continuously improving their processes and by providing high-quality education (Dumond \& Johnson, 2013; Psomas \& Antony, 2017). Such management practices adopted by HEls reflect the principles of total quality management (TQM). In the literature, it is adequately justified to accept the philosophy of TQM in higher educations.

The momentum of TQM has been so contagious that, although it started with its roots in manufacturing, branching off into services and healthcare, it now penetrates government and education as well (Mehta, Verma, \& Seth, 2014). A growing number of universities adopting TQM for the same reasons that led industry and government to embrace it: management systems are old-fashioned. They can no longer ensure success in an increasingly competitive world. Therefore, overcoming the current challenges in HEls requires implementing TQM as a way to continuously provide the quality of their education provision (Ardi, Hidayatno, \& Zagloel, 2012). TQM has also found its way into many international colleges and universities. Many HEls in developed countries such as the USA and the UK have tried out TQM (Chung Sea Law, 2010). There are also several examples of educational organizations in Turkey and Malaysia (Grant, Mergen, \& Widrick, 2005), Sweden, and, in fact, all around the world, which are performing quality work based on TQM (Mehta et al., 2014). Moreover, a wide variety of educational organizations internationally (for example, in the USA, Canada, Singapore, the UK, Switzerland, Australia, Romania, and Malaysia) have implemented quality management systems according to the ISO 9001 standard (Dumond \& Johnson, 2013), the principles of which are in line with the TQM philosophy. Obviously, in the dynamic environment of the world of higher education, TQM seems to be one of the most powerful techniques for dealing not only with challenges in the market but also with stakeholders (Mehta et al., 2014).

Based on the literature gap identified, many future research suggestions have been made by several authors. According to Dumond and Johnson (Dumond \& Johnson, 2013), further research is needed to gather empirical data to continue the investigation of quality management in education. Soria-Garcia and Martinez-Lorente (Soria-García \& MartínezLorente, 2014)suggested that the TQM empirical studies should take into account the holistic reality of the education sector. Given that quality education requires good and effective organization and management systems, it is worth researching several techniques from industrial organizations in education (Soria-García \& Martínez-Lorente, 2014)). Saiti (Saiti, 2012) also noted that, given the differences between education and industry, more research and analysis is required in the field of implementing the values of TQM in the education sector. The development of research in TQM in HEls also provides opportunities for researching the effects of different patterns in each country (Ardi et al., 2012). Similarly, other 
researchers (Psomas \& Antony, 2017) stated that further research is needed to evaluate the critical factors of TQM in higher education in several countries. From the above, it seems that future research studies will create more knowledge about the development and implementation of TQM in the education area of the Greek education sector. Finally, CalvoMora et al. (2005) noted that it would be appropriate to follow a longitudinal approach for future research in the field of TQM in HEls, given that quality assessment and improvement is a process that develops over time. From the above, it is apparent that future research studies will create more knowledge about the development and implementation of TQM in education.

\section{Conclusion}

The present study reviewed the body of literature concerning implementation of CSR and TQM in the education sector with a focus on 'PHEl's in UAE. From the reviewed researches, the following key statements can be highlighted: -

- There is a link between TQM \& CSR and any organizational performance, as evidenced by previous research.

- The environment in which higher education institutions (HEIs) operate is increasingly complex and challenging. Competition has increased, and previously anticipated government funding has become scarce.

- In UAE, HEls are still facing many challenges related to the immature growth of graduate studies.

- The quick establishment did not allow enough time for many private higher education institutes (PHEIs) to properly study the market before setting up.

- A growing number of universities adopt TQM as their management systems are oldfashioned and can no longer ensure success in an increasingly competitive world.

- Overcoming the current challenges in HEls requires implementing TQM to ensure the quality of their education provision continuously.

\section{Recommendations}

- It is recommended to implement TQM and CSR techniques in higher in higher education sector. Such methods are powerful enough to alleviate the issues associated with the dynamic environment of the world of higher education

- Implementing TQMCSR approaches should be thoroughly assessed

- More research should be devoted to investigating the leading causes that lead to financial failures and the termination of some PHEI's. In this regard, arguments have been made pertaining to the critical role of organizational strategic plans and procedures. However, such thoughts are inconclusive and need further critical investigation

\section{Acknowledgment}

This work was supported/funded by the Ministry of Higher Education under Fundamental Research Grant Scheme (FRGS/1/2019/SS03/UTM/02/8). 


\section{References}

Abu-Saad, I. (2016). Access to higher education and its socio-economic impact among Bedouin Arabs in Southern Israel. International Journal of Educational Research, 76, 96-103. doi:https://doi.org/10.1016/j.ijer.2015.06.001

Ahmed, A., \& Alfaki, A. I. M. (2013). Transforming the United Arab Emirates into a knowledgebased economy: The role of science, technology and innovation. World Journal of Science, Technology and Sustainable Development, 10(2), 84-102.

Ardi, R., Hidayatno, A., \& Zagloel, Y. M. T. (2012). Investigating relationships among quality dimensions in higher education. Quality Assurance in Education, 20(4), 408-428.

Ashour, S. (2019). How technology has shaped university 'students' perceptions and expectations around higher education: an exploratory study of the United Arab Emirates. Studies in Higher Education, 1-13.

Ashour, S., \& Fatima, S. K. (2016). Factors favouring or impeding building a stronger higher education system in the United Arab Emirates. Journal of Higher Education Policy and Management, 38(5), 576-591.

Bon, A. T., \& Mustafa, E. M. A. (2013). Impact of Total Quality Management on Innovation in Service Organizations: Literature Review and New Conceptual Framework. Procedia Engineering, 53, 516-529. doi:https://doi.org/10.1016/j.proeng.2013.02.067

Chung Sea Law, D. (2010). Quality assurance in post-secondary education: the student experience. Quality Assurance in Education, 18(4), 250-270.

Dumond, E. J., \& Johnson, T. W. (2013). Managing university business educational quality: ISO or AACSB? Quality Assurance in Education, 21(2), 127-144.

Evans, J. R., \& Lindsay, W. M. (2013). Managing for quality and performance excellence: Cengage Learning.

Grant, D., Mergen, E., \& Widrick, S. (2005). A comparative analysis of quality management in US and international universities. Quality control and applied statistics, 50(1), 59-62.

Hoang, D. T., Igel, B., \& Laosirihongthong, T. (2011). Total quality management (TQM) strategy and organisational characteristics: Evidence from a recent WTO member. Quality control and applied statistics, 56(5), 471-473.

Jain, R., Sinha, G., \& Sahney, S. (2011). Conceptualizing service quality in higher education. Asian Journal on Quality, 12(3), 296-314.

Karani, S. R., \& Bichanga, W. O. (2012). Effects of Total Quality Management implementation on business performance in service institutions: A case of Kenya Wildlife Services. International journal of Research studies in Management, 1(1), 59-76.

Kayani, T. (2012). Total quality management in classroom at university level in Islamabad city. Pakistan Journal of Commerce and Social Sciences (PJCSS), 6(2), 392-404.

Mahani, S., \& Molki, A. (2011). Internationalization of higher education: A reflection on success and failures among foreign universities in the United Arab Emirates. Journal of International Education Research (JIER), 7(3), 1-8.

Marshall, J. (2019). Introduction to comparative and international education: SAGE Publications Limited.

Mehta, N., Verma, P., \& Seth, N. (2014). Total quality management implementation in engineering education in India: an interpretive structural modelling approach. Total Quality Management \& Business Excellence, 25(1-2), 124-140.

Nasir, S. (2017). New ratings system for UAE universities. Khaleej Times. 
Psomas, E., \& Antony, J. (2017). Total quality management elements and results in higher education institutions: The Greek case. Quality Assurance in Education, 25(2), 206223.

Saiti, A. (2012). Leadership and quality management: An analysis of three key features of the Greek education system. Quality Assurance in Education, 20(2), 110-138.

Soria-García, J., \& Martínez-Lorente, Á. R. (2014). Development and validation of a measure of the quality management practices in education. Total Quality Management \& Business Excellence, 25(1-2), 57-79.

Thorpe, M., \& Connell, J. (2013). Industry clusters, Dubai and the GCC: The antidote for growth and innovation after the GFC. Resources and competitive advantage in clusters, 97112.

Vikash, N. (2015). Transnational Higher Education: Why It Happens and Who Benefits? International Higher Education, 0(58). doi:10.6017/ihe.2010.58.8466

Wilkins, S. (2010). Higher education in the United Arab Emirates: An analysis of the outcomes of significant increases in supply and competition. Journal of Higher Education Policy and Management, 32(4), 389-400.

Wilkins, S. (2019). The positioning and competitive strategies of higher education institutions in the United Arab Emirates. International Journal of Educational Management.

Wilkins, S., Balakrishnan, M. S., \& Huisman, J. (2012). Student choice in higher education: Motivations for choosing to study at an international branch campus. Journal of Studies in International Education, 16(5), 413-433.

Zhu, T. T., \& Zhang, Y. J. (2017). An investigation of disaster education in elementary and secondary schools: evidence from China. Natural Hazards, 89(3), 1009-1029. doi:10.1007/s11069-017-3004-2 